\title{
Immunological study of the rectal mucosa of men with and without human immunodeficiency virus infection
}

\author{
P E BISHOP, A McMILLAN, AND H M GILMOUR \\ From the Department of Genito-Urinary Medicine and Department of Pathology, University of Edinburgh, \\ Edinburgh
}

SUMMARY Biopsies of rectal mucosa were taken from 81 men and stained using cytochemical methods for $\mathrm{B}$ and $\mathrm{T}$ lymphocytes, $\mathrm{T}$ cell subsets, immunoglobulin containing plasma cells and mucosal mast cells. The patients studied included human immunodeficiency virus (HIV) infected and non-infected heterosexual and homosexual men, and homosexual men with rectal gonorrhoea. There were increased numbers of $\mathrm{T}$ lymphocytes in the lamina propria of the rectum in HIV infected individuals regardless of whether the infection had been acquired through anal intercourse or intravenous drug use. This increase resulted from a marked increase in the numbers of CD8 ${ }^{+}$ suppressor $\mathrm{T}$ cells, there also being a reduction in the numbers of $\mathrm{CD} 4^{+}$helper $\mathrm{T}$ cells. In non-HIV infected men with rectal gonorrhoea there were increased numbers of $\mathrm{CD}^{+} \mathrm{T}$ cells but no significant difference in numbers of $\mathrm{CD}^{+}$cells. No difference was seen in numbers of immunoglobulin containing plasma cells or mucosal mast cells between HIV infected and noninfected men.

In Western Europe and the United States of America sexually active homosexual men constitute the population group at most risk for acquiring the human immunodeficiency virus (HIV).' 2 Most studies have shown a clear association between anal intercourse, particularly penoreceptive, and acquisition of the virus. ${ }^{34}$ As the rectum seems to be the portal of entry of HIV it is surprising that there have been few reports of the immunohistology of the rectum in homosexual men. The present study was undertaken to discover if the cellular content of the lamina propria of the rectums of sexually active homosexual men was different from that of heterosexual men, and to assess the effect of gonococcal infection on the lymphocyte composition of the rectal mucosa.

\section{Methods}

PATIENTS AND CLINICAL METHODS

The study was approved by the Ethics Committee of the Lothian Health Board. Eighty one men were studied: nine healthy heterosexual men, five HIV

Address for correspondence: Dr A McMillan, Department of Genito-Urinary Medicine, The Royal Infirmary, Edinburgh EH3 9YW.

Received for publication 8 May 1987. infected intravenous drug users (all with persistent generalised lymphadenopathy, without history of homosexual contact) and 67 consecutive homosexual male patients attending the department (Table 1). All but three of the healthy homosexual men had been the recipient partners during anal intercourse.

After taking a careful history and completing a general physical examination, material for microbiological examination was obtained.s A sigmoidoscope, lightly lubricated with K-Y jelly (Johnson and Johnson, Slough, UK) was passed and using Patterson's forceps at least two biopsies were taken.

LABORATORY METHODS

One biopsy was carefully orientated on a glass slide, fixed in buffered formol sublimate and processed for paraffin sections for histological evaluation. A second similarly orientated biopsy was snap frozen in liquid nitrogen and subsequently embedded in OCT compound (Miles Scientific, Naperville, USA) for the preparation of cryostat sections. The block was sectioned immediately or stored at $-70^{\circ} \mathrm{C}$ for up to one week. A third biopsy, obtained from 24 consecutive patients, was fixed in Carnoy's fluid and processed for paraffin sections for staining for mast cells. 
Table 1 Diagnoses made in the 67 homosexual men studied

\begin{tabular}{lc}
\hline Diagnosis & Men affected $^{*}(n)$ \\
\hline Syphilis (early) & 2 \\
Rectal gonorrhoea & 9 \\
Non-gonococcal urethritis & 1 \\
Chlamydial infection of rectum & 1 \\
Anorectal herpes simplex infection & 2 \\
Perianal condylomata acuminata & 17 \\
Amocbiasis & 2 \\
Giardiasis & 2 \\
Enterobiasis & 1 \\
HIV infection & $9 \dagger$ \\
No infection identificd & 36 \\
\hline
\end{tabular}

* Some men had concurrent infections: + Eight men had persistent generalised lymphadenopathy, the other had no clinical evidence of HIV infection.

\section{IMMUNOCYTOCHEMICAL METHODS}

Cryostat sections at $4 \mu \mathrm{m}$ were cut at two levels and stained for lymphocyte subsets using an indirect immunoperoxidase method ${ }^{n}$ with the following monoclonal antisera: Pan-B/M708 (CD22, mature B cells, Dako Ltd., High Wycombe, UK), anti-Leu 4 (CD3a, mature $\mathrm{T}$ cells), anti-Leu 2a (CD8, suppressor/cytotoxic $\mathrm{T}$ cells) and anti-Leu $3 \mathrm{a}(\mathrm{CD} 4$, helper/inducer $\mathrm{T}$ cells) (all from Becton Dickinson, Laboratory Impex, Twickenham, UK).

Paraffin sections at 3-4 $\mu \mathrm{m}$ taken at two levels from 15 consecutive blocks were stained for plasma cells containing $\mathrm{IgA}, \mathrm{IgG}$ and $\mathrm{IgM}$ using a peroxidaseantiperoxidase (PAP) method.?

\section{STAINING FOR MAST CELIS}

Mucosal mast cells were stained with Astra blue (BDH Ltd., Poole, UK) and safranin as described by Strobel et al. ${ }^{\times}$

\section{HISTOMETRY}

Cells were counted using an eyepiece graticule marked with a $10 \times 10$ grid. The sections were examined under high power magnification (objective $\times 40$, eyepiece $\times 10$ ) and one edge of the grid aligned with the basement membrane of the surface epithelium. At this magnification the grid edge covered a length of $0.283 \mathrm{~mm}$, area $0.08 \mathrm{~mm}^{2}$. Where orientation of the sections allowed, five high power fields were counted (minimum three) by two observers independently. Areas including, or immediately adjacent to lymphoid aggregates were avoided. Interobserver variation was $<4 \%$ of the mean counts: both observers were unaware of the clinical diagnosis at the time of counting.

SEROLOGICAL METHODS

Sera were tested for antibody against HIV using
ELISA or indirect immunofluorescence methods with confirmation of positive results by western blotting. ${ }^{4}$

\section{STATISTICAL ANALYSIS}

The data obtained on the lymphocyte subset composition of the lamina propria were normally distributed and Student's $t$ test was used in their analysis. As the numbers of mucosal mast cells and immunoglobulin containing plasma cells were not normally distributed, Wilcoxon's rank-sum test was used. The $\chi^{2}$ test was used to compare the histological grading of the rectal mucosa.

\section{Results}

HISTOLOGICAL GRADING (Table 2)

The histology of the rectum was normal (grade A) in the 14 heterosexual men studied, including the five intravenous drug users seropositive for HIV. A mild, non-specific proctitis was found in five of 14 HIV infected and six of 36 non-infected homosexual men. There was no significant difference in the prevalence of inflammatory changes between HIV infected and non-infected men $\left(\chi^{2}=1 \cdot 79 ; p>0 \cdot 10\right)$.

\section{LYMPHOCYTE SUBPOPULATIONS WITHIN THE L.AMINA PROPRIA (Figure)}

CD22 B cells

Using the antiserum $\mathrm{M} 708$, which is broadly reactive with mature B cells, no staining was seen in the lamina propria. All B cells reactive with this antiserum were confined to organised lymphoid aggregates.

Table 2 Histological grading of rectal biopsies in relation to HIV infection and gonorrhoea

\begin{tabular}{|c|c|c|c|}
\hline \multirow[b]{2}{*}{ Group } & \multicolumn{2}{|c|}{ Histological grade* } & \multirow[b]{2}{*}{ Total } \\
\hline & $A$ & $B$ & \\
\hline $\begin{array}{l}\text { Non-infected, non-intravenous } \\
\text { drug-using heterosexual men }\end{array}$ & 9 & 0 & 9 \\
\hline $\begin{array}{l}\text { HIV-infected heterosexual } \\
\text { intravenous drug users }\end{array}$ & 5 & 0 & 5 \\
\hline Non-infected homosexual men & $31 \div$ & 5 & 36 \\
\hline HIV infected homosexual men & $9 \ddagger$ & 5 & 14 \\
\hline $\begin{array}{l}\text { Homosexual men with rectal } \\
\text { gonorrhoea but no serological } \\
\text { evidence of HIV infection }\end{array}$ & 7 & 2 & 9 \\
\hline
\end{tabular}



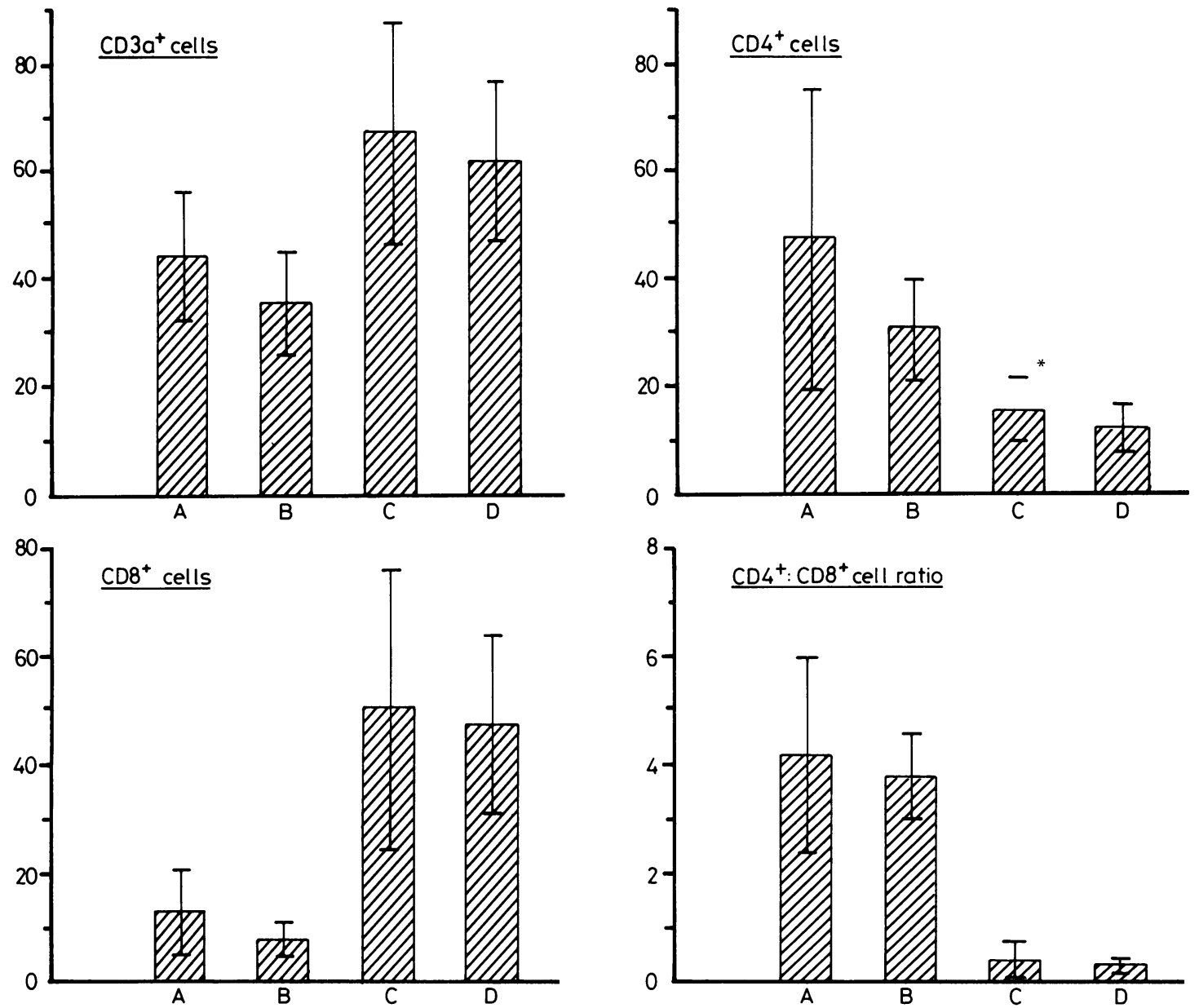

Figure Numbers of $T$ cells per unit area $\left(0.08 \mathrm{~mm}^{2}\right)$ and ratio of $C D 4^{1}: C D 8^{+}$cells in the lamina propria of the rectum. $A=$ non-infected heterosexual men $(n=5) ; B=n o n$-infected homosexual men $(n=12) ; C=H I V$ infected homosexual men $(n=9) ; D=H I V$ infected heterosexual men $(n=5)$; *errorbar.

CD3a+T cells

Within the unit area of $0.08 \mathrm{~mm}^{2}$ there was no significant difference in the number of $\mathrm{T}$ cells between non-infected heterosexual $(44.0 \pm 11.8)$ and non-infected homosexual men $(35 \cdot 5 \pm 9 \cdot 5)(\mathrm{t}=1 \cdot 57$; $p>0 \cdot 1)$. Similarly, the mean numbers of $T$ cells in the mucosa of HIV infected homosexual men $(67 \cdot 3 \pm$ 20.9) and intravenous drug users $(62 \cdot 0 \pm 14 \cdot 9)$ were not significantly different $(t=0 \cdot 50 ; p>0 \cdot 5)$. The mean numbers of $\mathrm{CD}^{2} \mathrm{a}^{+}$cells in the lamina propria of HIV infected homosexual men and intravenous drug users were significantly higher than those of the noninfected men $(t=5 \cdot 15 ; \mathrm{p}<0 \cdot(001)$.

CD4' cells

The mean number of $\mathrm{CD} 4$ cells in the mucosa of
HIV infected homosexual men $(16 \cdot 1 \pm 6 \cdot 3)$ was lower than that of the non-infected homosexual men $(30 \cdot 3 \pm 9 \cdot 4)$ : this difference was highly significant $(\mathrm{t}=3.91 ; \mathrm{p}<0.001)$. Similarly there was a significant difference between HIV infected (12.5 \pm 4.7$)$ and non-infected $(47.6 \pm 28 \cdot 1)$ heterosexual men $(\mathrm{t}=2 \cdot 75 ; \mathrm{p}<0 \cdot 05)$.

\section{CD8 $8^{+}$cells}

The mean number of $\mathrm{CD} 8^{+}$cells in the lamina propria was significantly greater in the HIV infected $(50 \cdot 4 \pm 26 \cdot 1)$ than in the non-infected $(8 \cdot 2 \pm 2 \cdot 8)$ homosexual men $(t=5 \cdot 62 ; p<0 \cdot 001)$. A similar finding was noted in the HIV infected $(47.7 \pm 16.5)$ and non-infected $(12 \cdot 8 \pm 8 \cdot 2)$ heterosexual men $(t=4 \cdot 23$; $\mathrm{p}<0 \cdot 01)$. 
$C D 4^{+}: C D 8^{*}$ cell ratio

As can be seen from the Figure, the $\mathrm{CD}^{+}: \mathrm{CD} 8^{+}$ cell ratio was significantly lower in the two HIV infected groups $(0.4 \pm 0.3)$ compared with the noninfected groups $(3.9 \pm 1 \cdot 1) \quad(\mathrm{t}=11 \cdot 3 ; \mathrm{p}<0.001)$. There was no significant difference at the $1 \%$ level between heterosexual and homosexual patients in each group.

\section{Influence of infection with Neisseria gonorrhoeae}

Sections from eight of the nine men with untreated rectal gonorrhoea but no serological evidence of HIV infection were examined (Table 3 ). Only two of these men had a mild, chronic proctitis (grade B) (Table 2). The mean numbers of $\mathrm{CD} 3 \mathrm{a}^{\circ}$ and $\mathrm{CD} 8^{+}$cells was significantly higher than in non-infected homosexual men; there was no significant difference between these groups in the mean number of $\mathrm{CD} 4{ }^{+}$cells.

IMMUNOGLOBULIN CONTAINING PLASMA CELLS There was no significant difference at the $1 \%$ level in the numbers of IgG, IgA or IgM-containing plasma cells between HIV infected and non-infected homosexual men (Table 4).

MAST CELLS

There was no significant difference at the $1 \%$ level in the numbers of mucosal mast cells between noninfected (median $=8$ per unit area, semi-interquartile range $5 \cdot 5-10 ; n=17)$ and $\mathrm{HIV}$-infected men (range $=$ $3 \cdot 3-10 \cdot 5 ; n=4)$. Sections from the other three patients were not examined because of current infection.

\section{Discussion}

This study has shown that in HIV infected individuals, regardless of how the infection had been acquired, the numbers of $\mathrm{CD} 3 \mathrm{a}^{\circ} \mathrm{T}$ cells within the lamina propria of the rectum are increased. This results from markedly increased numbers of CD8. cells, despite reduced numbers of $\mathrm{CD} 4$ cells. Although Rodgers et al " noted a similar decrease in the $\mathrm{CD} 4$ lymphocyte content of the lamina propria of the small intestine of 12 homosexual men with persistent generalised lymphadenopathy or AIDS, the numbers of $\mathrm{CD} 3 \mathrm{a}^{+}$cells were significantly lower than in biopsies from healthy heterosexual and homosexual men. In haematoxylin and eosin stained sections, however, they found that the numbers of mononuclear cells per unit area of mucosa from HIV infected men were greater than from non-infected men. Increases in $\mathrm{CD} 8^{+}$cells in the mucosa of men with AIDS did not reach statistical significance.

Human immunodeficiency virus is tropic and cytopathic for CD4-bearing lymphocytes, and the decreased numbers of $\mathrm{CD} 4$ cells in the small intestinal and rectal mucosa probably results directly from HIV infection. Janossy et al " noted CD4 ${ }^{\prime}$ cell depletion in the paracortex of lymph nodes removed from men with persistent generalised lymphadenopathy. In some cases this was less severe than in the peripheral blood, suggesting that $\mathrm{CD} 4{ }^{+}$cells may settle preferentially in the tissues. Unfortunately in the present study it was not possible to compare the tissue and peripheral blood lymphocyte subset composition. The reason for the disparity in the numbers of $\mathrm{CD} 8^{+}$

Table 3 Lymphocyte subpopulations within the lamina propria of the rectums of homosexual men with gonorrhoea

\begin{tabular}{|c|c|c|c|c|}
\hline \multirow[b]{2}{*}{ Group } & \multirow[b]{2}{*}{$n$} & \multicolumn{3}{|c|}{ Mean number of cells (SD) per unit area } \\
\hline & & $C D 3 a^{+}$ & $\mathrm{CD4}^{+}$ & $C D 8^{+}$ \\
\hline \multirow{3}{*}{$\begin{array}{l}\text { A men with rectal gonorrhoca } \\
\text { B non-infected homosexual men } \\
\text { Comparing A with B }\end{array}$} & 8 & $45 \cdot 4(10 \cdot 7)$ & $34 \cdot 3(15 \cdot 2)$ & $14 \cdot 5(10 \cdot 2)$ \\
\hline & 12 & $35 \cdot 6 \quad(9 \cdot 6)$ & 3()$\cdot 3 \quad(9 \cdot 4)$ & $8 \cdot 2(2 \cdot 8)$ \\
\hline & & $t=2 \cdot 17$ & $t=0.73$ & $t=2 \cdot(05$ \\
\hline
\end{tabular}

Table 4 Immunoglobulin-containing plasma cells within the lamina propria of the rectums of HIV infected and non-infected homosexual men

Median number (semi-interquartile range) per unit area of plasma cells containing

\begin{tabular}{|c|c|c|c|c|}
\hline \multirow[b]{2}{*}{ Group } & \multirow[b]{2}{*}{$n$} & \\
\hline & & $\lg G$ & $\lg A$ & $\lg M$ \\
\hline \multirow{3}{*}{$\begin{array}{l}\text { A HIV infected homosexual men } \\
\text { B non-infected homosexual men } \\
\text { Comparing A with B }\end{array}$} & 8 & $0.7(0-5 \cdot 7)$ & $15 \cdot 4(2 \cdot 3-7 \cdot 0)$ & $5 \cdot 7(3 \cdot 3-15)$ \\
\hline & 7 & $3 \cdot 7(1-8 \cdot 3)$ & $45 \cdot()(24 \cdot 7-67)$ & $6 \cdot 3(3 \cdot 3-12 \cdot 5)$ \\
\hline & & $p>0 \cdot 1$ & $p>0 \cdot 1$ & $\mathrm{p}>0 \cdot 1$ \\
\hline
\end{tabular}


cells between Rodgers and colleagues "' and our study is not immediately apparent. Among sexually active homosexual men, infection with Epstein-Barr virus (EBV) and cytomegalovirus (CMV) is universal, ${ }^{12}$ and there are data to suggest that HIV infection may reactivate EBV. ${ }^{13}$ Reactivation of these viruses is sometimes associated with increased numbers of CD8-bearing lymphocytes in the peripheral blood. ${ }^{13}$ Unfortunately facilities for viral culture from our patients were not available. Although the number of CD8 cells in the peripheral blood of homosexual men infected with HIV is often greater than normal, ${ }^{13}$ it is difficult to know whether this represents a direct effect of that infection or the result of reactivation of latent viruses such as CMV or EBV. After acute HIV infection, there is an increase in the number of CD8 cells in the peripheral blood. ${ }^{14}$ The only patient in our series who had a mononucleosis like illness followed by seroconversion had the most marked infiltration of the lamina propria with CD8 cells of all the patients studied. The mean number of CD4 cells ( 33 per unit area) was the highest of the HIV infected homosexual men but within one standard deviation of the mean value for non-infected men. As a result of the large increase in $\mathrm{CD} 8^{+}$cells the $\mathrm{CD} 4^{\circ} \mathrm{CD} 8^{\text {. }}$ ratio was low $(0 \cdot 4)$. None of the other patients, however, were studed at this stage of infection (median duration of lymphadenopathy 12 months, range five to 24 months).

Although in most studies receptive anal intercourse has been shown to be a risk factor for the development of HIV antibody, ${ }^{3}$ this view was challenged by Weber et al ${ }^{\text {s }}$ who did not find an association between anal intercourse and seropositivity for HIV. These data, however, suggested that concurrent or recent sexually transmitted disease might be an important cofactor in developing HIV antibody. They postulated that acute infection may lead to $T$ cell activation with viral replication leading to a humoral response. In about $40 \%$ of patients gonococcal infection of the rectum is associated with increased numbers of chronic inflammatory cells in the lamina propria.? We have shown that this results from infiltration with CD8 lymphocytes. Class II MHC (HLA-D region) antigens were expressed on some of these cells (data not shown) but, as a clear differentiation between stained lymphocytes and macrophages was impossible, conclusions regarding the activation of the lymphocytes cannot be drawn. Although many cells in the lamina propria expressed class II MHC antigens, these antigens were only expressed by the surface epithelium when overlying organised aggregates of lymphoid tissue. ${ }^{\text {th }}$

Mast cells are involved in immediate and delayed onset hypersensitivity reactions, regulation of immune responses, direct cytotoxicity and the potentiation of eosinophil and macrophage cytotoxicity. ${ }^{17}$ Although increased numbers of mucosal mast cells were noted in men with AIDS associated diarrhoea,${ }^{1 \times}$ we did not find a difference in the median numbers of cells per unit area between HIV and nonHIV infected men.

Secretory $\operatorname{IgA}$ is important in the host defence against infection at mucosal surfaces. ${ }^{19}$ As $\mathrm{CD} 4{ }^{+}$cells play a part in the regulation of IgA responses, ${ }^{17}$ HIV infection might result in impaired mucosal immunity. Indeed, intestinal infection of such individuals with organisms such as Crypto-sporidium spp that generally produce a transient diarrhoeal illness is well recognised." Although we did not find a significant difference in the median numbers of $\operatorname{IgA}$ containing plasma cells within the lamina propria of HIV infected and non-infected men, a functional impairment of $\operatorname{IgA}$ secretion is not precluded.

In conclusion, our findings confirm that abnormalities of lymphocyte subset distribution within the lamina propria of the rectums of HIV infected men are common, but their significance with respect to mucosal immunity is still uncertain.

We would like to thank Dr A E Dewar, Department of Pathology, University of Edinburgh, for her helpful advice. This work was supported by Scottish Home and Health Department, Biomedical Research Committee grant K/MRS/50/C685.

\section{References}

1 Cheingsong-Popov R, Weiss RA, Dalgleish A, et al. Prevalence of antibody to human T-lymphotropic virus type III in AIDS and AIDS-risk patients in Britain. Lancet 1984: ii: 477-80.

2 Gallo RC. Salahuddin SZ, Popvic M, et al. Frequent detection and isolation of cytopathic retroviruses (HTLV-III) from patients with AIDS and at risk for AIDS. Science 1984; 224: 50()-3.

3 Melbye M, Biggar RJ, Ebbesen P, et al. Seroepidemiology of HTLV-III antibody in Danish homosexual men: prevalence, transmission and disease outcome. $\mathrm{Br}$ Med J 1984; 289: 573-5.

4 Goedert JJ, Sarngadharan MG, Biggar RJ, et al. Determinants of retrovirus (HTLV-III) antibody and immunodeficiency conditions in homosexual men. Lancet 1984; ii: 711-6.

5 McMillan A. Lee FD. Sigmoidoscopic and microscopic appearance of the rectal mucosa in homosexual men. Gut 1981; 22: 1035-41.

6 Salter DM. Krajewski AS. Dewar AE. Immuno-histochemical staining of non-Hodgkin's lymphoma with monoclonal antibodies specific for the leucocyte common antigen. $J$ Pathol 1985; 146: 345-53.

7 McMillan A. McNeillage G, Gilmour HM, Lee FD. Histology of rectal gonorrhoea in men, with a note on anorectal infection with Neisseria meningitidis. J Clin Pathol 1983; 36: 511-4. 
8 Strobel S, Miller HRP, Ferguson A. Human intestinal mucosal mast cells: evaluation of fixation and staining techniques. J Clin Pathol 1981; 34: 851-8.

9 Peutherer JF, Edmond E. Simmonds P. Dickson JD. Bath GE. HTLV-III antibody in Edinburgh drug addicts. Lancet 1985; ii: 1129-30.

10 Rodgers VD, Fassett R, Kagnoff MF. Abnormalities in intestinal mucosal T-cells in homosexual populations including those with the lymphadenopathy syndrome and acquired immunodeficiency syndrome. Gastroenterology 1986; 90: 552-8.

11 Janossy G. Pinching AJ, Bofill M, et al. An immunohistological approach to persistent lymphadenopathy and its relevance to AIDS. Clin Exp Immunol 1985; 59: 257-66.

12 Detels R, Visscher BR. Fahey JL, et al. The relation of cytomegalovirus and Epstein-Barr virus antibodies to T-cell subsets in homosexually active men. JAMA 1984; 251: $1719-22$.

13 Rinaldo CR, Kingsley LA, Lyter DW, et al. Association of HTLV-III with Epstein-Barr virus infection and abnormalities of T-lymphocytes in homosexual men. $J$ Infect Dis 1986; 154: 556-61.

14 Cooper DA, Gold J, Maclean P, et al. Acute AIDS retrovirus infection. Definition of a clinical illness associated with seroconversion. Lancet 1985; i: 537-40.

15 Weber JN, McCreaner A. Berrie E, et al. Factors affecting seropositivity to human T-cell lymphotropic virus type III (HTLV-III) or lymphadenopathy associated virus (LAV) and progression of disease in sexual partners of patients with AIDS. Genitourin Med 1986; 62: $177-80$.

16 Bishop PE, McMillan A. Gilmour HM. A histological and immunocytochemical study of lymphoid tissue in rectal biopsies from homosexual men. Histopathology. (In press)

17 Elson CO, Kagnoff MF. Fiocchi C, Befus AD, Targan $S$. Intestinal immunity and inflammation: recent progress. Gastroenterology 1986; 91: 746-68.

18 Kotler DP, Gaetz HP. Lange M, Klein EB, Holt PR. Enteropathy associated with the acquired immunodeficiency syndrome. Ann Intern Med 1984; 101: $421-8$.

19 Waldman RH, Ganguly R. Immunity to infections on secretory surfaces. J Infect Dis 1974; 130: 419-40.

20 Soave R, Danner RL, Honig CL, et al. Cryptosporidiosis in homosexual men. Ann Intern Med 1984; 100: $504-11$. 